\title{
The Description of Polymorphism of CYP1A1*2A rs4646903 (T>C) Gene as Colorectal Cancer Risk Factor In Medical Study Programs and Doctor Profession 2012-2014 UIN Syarif Hidayatullah Jakarta
}

\author{
Nurul Fathimah, Chris Adhiyanto, Zeti Harriyati, Hari Hendarto, Achmad Lutfi \\ Medical Study Program and Doctor Profession \\ Faculty of Medicine and Health Sciences \\ Syarif Hidayatullah State Islamic University \\ Jakarta, Indonesia \\ Nurulfathimah1@gmail.com
}

\begin{abstract}
Colorectal cancer is the third leading cause of death from all cancer cases in Indonesia. From previous research it is known that there is a relationship between genetic polymorphism of cytochrome P450 (CYP) with the incidence of colorectal cancer. Therefore, research team of FKIK UIN Syarif Hidayatullah Jakarta and Fatmawati General Hospital work together to evaluate the frequency of SNP CYP1A1*2A rs $4646903(T>C)$ allele in Medical Study Program and Doctor Profession of FKIK UIN Syarif Hidayatullah Jakarta. Methods: Blood sampling was taken from healthy student of Medical Study Program and Doctor Profession of FKIK UIN Syarif Hidayatullah Jakarta. Genotype examination was performed by PCR-RFLP method. Results and Conclusions: Based on screening results, most of genotype is a heterozygot, while wild type and mutant are minority. So most of the students has polymorphism SNP CYP1A1*2A rs4646903 (T>C)
\end{abstract}

Keywords-Colorectal Cancer; CYP1A1*2A rs4646903; single nucleotide polymorphism

\section{INTRODUCTION}

Colorectal cancer (CRC) is the third most common cancer in the world and its prevalence has been steadily increasing over the last century. It is the fourth most common cancer that cause death in the world. ${ }^{1}$ Thus, CRC is the third leading cause of death from all cancer cases in Indonesia, which prevalence at 2013 is $1,4 \%$ or about $347.792 .^{2}$ Cytochrome P450 (CYP) enzymes are a critical importance for the metabolism of xenobiotic, which function is detoxification. If the process is failed, it can cause carcinogenesis. ${ }^{3-6}$ It revealed that these polymorphisms were associated with increased enzyme activity to activate carcinogens. The CYP1A1 gene is located on the long arm of chromosome $15 q 22$-qter. ${ }^{7}$ Previous studies shown that mutant homozygous and heterozygous allele of $\mathrm{CYP} 1 \mathrm{~A} 1 * 2 \mathrm{~A}$ have a risk of colorectal cancer. The frequency of the CYP1A $1 * 2 \mathrm{~A}$ allele is about $9.4 \%$ in
Caucasians, 35.8\% in Asians, and $23.8 \%$ in Africans. ${ }^{8-9}$ The aim of the present study was to test for potential association between the CYP1A $1 * 2 \mathrm{~A}$ and the risk of CRC in student of Medical Study Program and Doctor Profession of Faculty of Medicine and Health Sciences, Syarif Hidayatullah State Islamic University, Jakarta.

\section{MATERIALS AND METHODS}

\section{A. Sample collection}

This study was conducted after review and approval of the Institutional Review Board of the Ethics Committee at FKIK UIN Syarif Hidayatullah Jakarta. Blood samples were collected from 74 healthy subjects $(27$ males, 47 females, age range 17-23 years; mean age 19,78 years). The control samples were collected from subjects referred to the university.

Tissue samples to be used for RNA analysis were immediately submerged in RNA later solution (Ambion, Courtabeuf, France) to avoid RNA degradation, stored at $4{ }^{\circ} \mathrm{C}$ for $24 \mathrm{~h}$, and then stored at $-20^{\circ} \mathrm{C}$ until needed

\section{B. DNA Isolation}

Genomic DNA was isolated from blood samples using Geneaid GB100. Concentration, purity, and quality of the isolated RNA were determined using the DeNovix DS-11 Spectrophotometer.

\section{Genotyping}

Genotyping for the CYP1A1*2A allele (T>C; rs4646903) was achieved by polymerase chain reaction restriction fragment length polymorphism (PCR RFLP). Briefly, a 338 bp DNA fragment containing the polymorphic MspI restriction site, corresponding to the 3 ' end of CYP1A1, was amplifed 

using the following
TAGGAGTCTTGTCTCATGCCT
primers:
and
$5^{\prime}-$

CAGTGAAGAGGTGTAGCCGCT.

The PCR was carried out in a final volume of $25 \mu 1$ containing 12,5 $\mu$ l KAPA2G Fast ReadyMix + dye (2X) PCR kit (Headquarters, USA), $1 \mu \mathrm{l}$ of each primer, $5 \mu \mathrm{l}$ of the extracted genomic DNA, 5,5 $\mu \mathrm{l}$ of $\mathrm{dH} 2 \mathrm{O}$. Cycling conditions were as follows: pre incubation step at $95^{\circ} \mathrm{C}$ for $2 \mathrm{~min}, 56 \mathrm{sec}$; 40 cycles consisting of denaturation at $95^{\circ} \mathrm{C}$ for $15 \mathrm{sec}$, annealing at $65^{\circ} \mathrm{C}$ for $15 \mathrm{sec}$, and extension (elongation) at $72^{\circ} \mathrm{C}$ for $20 \mathrm{sec}$; followed by a final extension step at $72^{\circ} \mathrm{C}$ for 2 min. PCR products were analyzed using $1 \%$ agarose gel electrophoresis and the size of the products were determined by including $100 \mathrm{bp}$ DNA ladder on the gel and visualization using AttoPrintgraph (Printgraph ATTO AE-6905 CF CCD camera controller).

Finally, $5 \mu$ l of each PCR product was digested 4 hours at $37^{\circ} \mathrm{C}$ with $1,5 \mu \mathrm{l}$ of $\mathrm{MspI}$ restriction enzyme. The digestion products were subjected to electrophoresis on $1.5 \%$ agarose and on Agarose LE (Kit Code No.11-685-660-001, Roche Diagnostics) using elektroforesis ATTO My Power II 300 AE8135 electrophoresis system at $90 \mathrm{~V}, 1 \mathrm{~A}$ and stained with DNA Loading Dye AM29502.

\section{RESULT}

The PCR result are illustrates in Figure 1 and the CYP1A1*2A allele ( $\mathrm{T}>\mathrm{C}$; rs4646903) genotypes are illustrated in Figure 2. The distribution of CYP1A $1 * 2 \mathrm{~A}$ allele ( $\mathrm{T}>\mathrm{C}$; rs4646903) genotypes among the tested subjects and statistical analysis of the obtained data are detailed in Table 1. The frequency of the CYP1A1 wild type homozygous allele was $23 \%$, mutant homozygous allele was $20.3 \%$, heterozygous allele was $56.7 \%$ in healthy subjects.

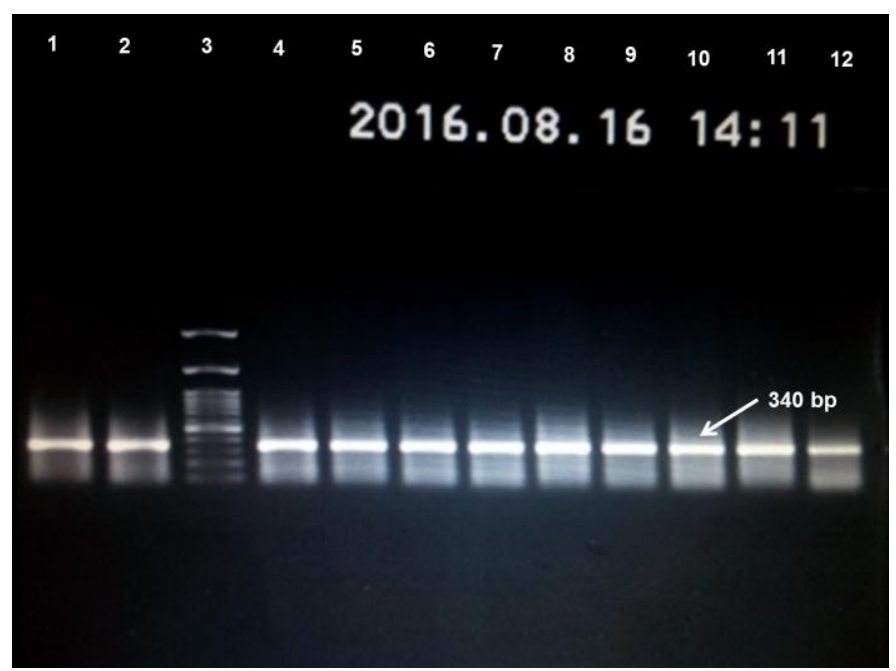

Fig. 1. Lanes 1-3 represent control uncut PCR products at $340 \mathrm{bp}$. Lane 3 represents DNA ladder molecular weight markers.

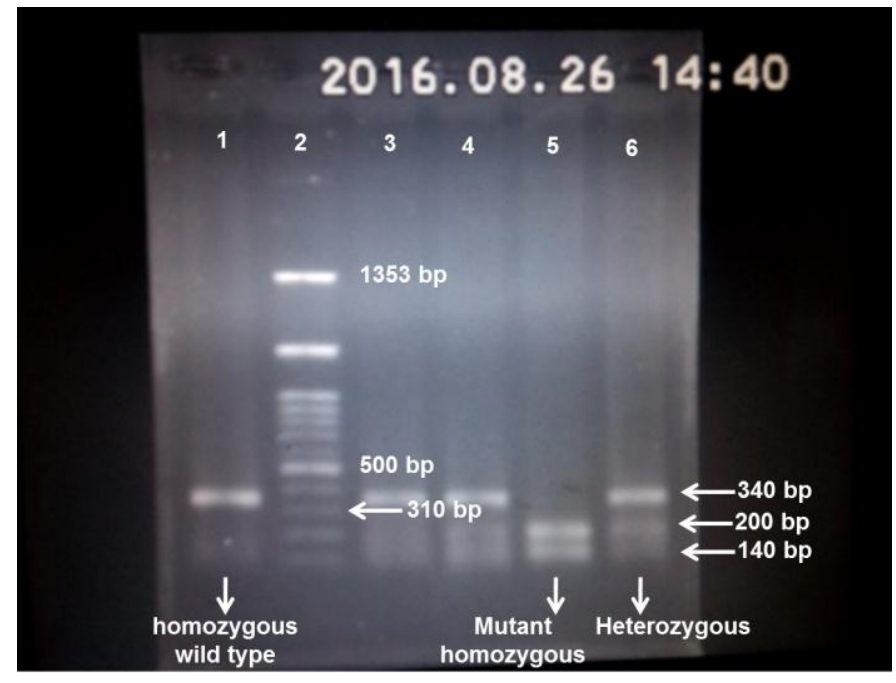

Fig. 2. Agarose gel (2.5\%) Electrophoresis for PCR Products of CYP1A1*2A allele ( $>$ C; rs4646903).

The amplicon is subjected to digestion with MspI prior to electrophoresis. The $340 \mathrm{bp}$ uncut amplicon (upper band) reveals CYP1A $* 2 A$ allele $(\mathrm{T}>\mathrm{C} ; \quad \mathrm{rs} 4646903) \mathrm{wt} / \mathrm{wt}$ homozygous wild type (lane 1), the mutant homozygous (lane 5) shows two fragments $(200$ and $140 \mathrm{bp})$, and the heterozygous genotype (lane $3,4,6$ ) presents three fragments (the uncut 340-bp fragment and two restriction fragments of 200 and $140 \mathrm{bp}$ )

TABLE I. ANALYSIS PCR RFLP OF CYP1A1*2A ALLELE (T>C; RS4646903) GENOTYPE

\begin{tabular}{|l|c|c|}
\hline Genotyping & Frequency & Percentage (\%) \\
\hline Wild type homozygous & 17 & 23,0 \\
\hline Mutant homozygous & 15 & 20,3 \\
\hline Heterozygous & 42 & 56,7 \\
\hline Total & 74 & 100,0 \\
\hline
\end{tabular}

\section{DISCUSSION}

The results of genotyping CYP1A1*2A rs4646903 (T>C) genotyping using RFLP PCR technique in the students of Medical Study Program and Doctor Profession of FKIK UIN Syarif Hidayatullah Jakarta from 74 samples,wild type homozygous allele was $23 \%$, mutant homozygous allele was $20,3 \%$, heterozygous allele was $56,7 \%$ in healthy subjects. Based on screening results, most of genotype is a heterozygot, while wild type and mutant are minority. So most of the students has polymorphism SNP CYP1A1*2A rs4646903 (T> C). This is reinforced by previous studied that CYP1A $1 * 2 \mathrm{~A}$ is a large variety of alleles owned by residents of the Asian region (Japan) from Caucasians. The frequency of the CYP1A $1 * 2 \mathrm{~A}$ allele is about $9.4 \%$ in Caucasians, $35.8 \%$ in Asians, and $23.8 \%$ in Africans. ${ }^{8-9}$

CYP1A1*2A allele $(\mathrm{T}>\mathrm{C}$; rs4646903) allele might thus exhibit higher rates of carcinogen activation than individuals with the wild-type allele. From the studied gene variations, two genetically linked polymorphisms of CYP1A1, *2A and $* 2 \mathrm{C}$, conferred at least 3 -fold increases in its catalytic 
activity. ${ }^{10}$ Similar to the four studies carried out in Asian populations, the carriers of the $\mathrm{C}$ allele of $\mathrm{CYP} 1 \mathrm{~A} 1 * 2 \mathrm{~A}$ have a 2.53-fold increased risk for CRC compared with the $\mathrm{T}$ allele carriers. $8,9,11,12$ Previous studies at Japan shown that heterozygous allele of $\mathrm{CYP} 1 \mathrm{~A} 1 * 2 \mathrm{~A}$ have a risk of colorectal cancer. ${ }^{13}$

Wes suggest to do other diagnostic criteria such as FOB (Fecal Occult Blood) examination, look for data about smoking habits, consumption of red meat, family history which are some risk factors for colon cancer and educate the students of Medical Study Program and Doctor Profession of FKIK UIN Syarif Hidayatullah Jakarta due to the association between the CYP1A1*2A rs4646903 gene with the risk factor for colorectal cancer,

\section{ACKNOWLEDGMENT}

The authors extend their appreciation to FKIK UIN Syarif Hidayatullah Jakarta, Fatmawati General Hospital, DIKTIS DEPAG RI for funding the work through the research group project.

\section{REFERENCES}

[1] Ferlay J, Soerjomataram I, Ervik M, editor. "Cancer Incidence and Mortality Worldwide 2012" [internet]. France: International Agency for Research on Cancer; 2013 [acessed on Jul 13th 2017]. Available at http://globocan.iarc.fr/Pages/fact_sheets_population.aspx

[2] Anonim. "Situasi Penyakit Kanker 2015" [Internet]. Indonesia: Kementerian Kesehatan RI, Infodatin Pusat Data dan Informasi; 2015 [diakses pada 19 Maret 2016]. Available at http://www.depkes.go.id/resources/download/pusdatin/infodatin/infodati n-kanker.pdf
[3] Nebert DW, Nelson DR, Coon MJ, et al, "The P450 superfamily: update on new sequences, gene mapping, and recommended nomenclature," DNA and Cell Biology. 1991 Jan;10(1):1-14.

[4] Nebert DW, "Role of genetics and drug metabolism in human cancer risk. Mutat Res,” 1991 Apr; 247(2):267-81.

[5] Slattery ML, Samowtiz W, Ma K. et al, "CYP1A1, cigarette smoking, and colon and rectal cancer," Am. J. Epidemiol. 2004 Nov;160(9):842852.

[6] Kury S, Buecher B, Robiou-du-Pont S, et al, "Combinations of cytochrome P450 gene polymorphisms enhancing the risk for sporadic colorectal cancer related to red meat consumption," Cancer Epidemiol Biomarkers Prev. 2007 Jul;16(7):1460-7.

[7] Corchero J, Primprale S, Kimura S, et al, "Organization of the CYP1A cluster on human chromosome 15: implications for gene regulation," Pharmacogenetics.2001 Feb;11(1):1-6.

[8] O* zhan G, Mutur M, Ercan G, et al, "Genetic variations inthe xenobiotic-metabolizing enzymes CYP1A1, CYP1A2,CYP2C9, CYP2C19 and susceptibility to colorectal canceramong Turkish people,"Genet Test Mol Biomarkers. 2014 Apr; 18(4):223-8.

[9] Garte S, Gaspari L, Alexandrie AK, et al, "Metabolicgene polymorphism frequencies in control populations,"Cancer Epidemiol Biomarkers Prev. 2001 Dec;10(12):1239-48

[10] Garte S. The role of ethnicity in cancer susceptibility gene polymorphisms: The example of CYP1A1," Carcinogenesis. 1998 Aug;19(8):1329-32.

[11] Landi MT, Bertazzi PA, Shields PG, et al, "Association between CYP1A1 genotype, mRNA expression and enzymatic activity in humans," Pharmacogenetics.1994 Oct;4(5):242-6.

[12] Kawajiri K, Nakachi K, Imai K, et al, "The CYP1A1gene and cancer susceptibility. Crit Rev Oncol Hematol. 1993 Feb;14(1):77-87.

[13] Yoshida K, Osawa K, Kasahara M, et al, "Association of CYP1A1, CYP1A2, GSTM1 and NAT2 gene polymorphisms with colorectal cancer and smoking,"Asian Pac J Cancer Prev. 2007 Jul-Sep;8(3):43844 . 